\title{
新規なネットワークポリマーとしての高性能ポリベンゾオキサジン
}

熱硬化性樹脂ポリベンゾオキサジンは, 従来のフェノール樹脂と同様の耐熱性, 難燃性, 電気特性などを有 するだけでなく, 分子設計の自由度が高く, 揮発性副生成物を発生しないなど, 多くの特徵を有するため, 新規なフェノール樹脂として期待されている。本稿では，ポリベンゾオキサジンの課題の克服を目的とした さまざまな研究の現状と今後の展望について概説する。

\section{竹市 力*・河内岳大**}

\section{High Performance Polybenzoxazines as a Novel Type of Network Polymer}

Tsutomu TAKEICHI* and Takehiro KAWAUCHI**

School of Materials Science, Toyohashi University of Technology

E-mail: takeichi@tutms.tut.ac.jp*

Abstract: Polybenzoxazines that can be obtained by the thermally induced ring-opening polymerization of cyclic benzoxazine monomers are expected as a novel type of phenolic resins. Herein, we report on our various approaches for performance enhancement of polybenzoxazine, including design of novel monomers, design of high molecular weight polymeric precursors, polymer alloys, and hybridization with inorganics.

Keywords: Thermoset/Ring-Opening Polymerization/Thermal Properties/Toughness/Polymer Alloy/Organic-Inorganic Hybrid/ Nanocomposite

\section{1.はじめに}

フェノール樹脂は約 100 年の歴史をもつ合成プラス チックであり, 優れた特性を活かして幅広く応用されてい る。しかしながら, フェノール樹脂は, 重合触媒が必要で あり, 前駆体の保存安定性が低く, 硬化過程で揮発性副生 成物が生成するため体積収縮が大きく, 空孔が生成しやす いなど, いくつかの欠点がある。

ポリベンゾオキサジンは環状モノマーの開環重合で得ら れる一連の新規なフェノール樹脂である11。代表的な環状 モノマー (B-a) の合成スキームと硬化物ポリベンゾオキサ ジン (PB-a) の構造を図 1 に示す。モノマー合成が簡単で あり, かつ, 原料であるフェノール類やアミン類の種類が 多いことは, モノマーの分子設計・材料設計の観点加ら非 常に魅力的である。重合は環状モノマーの開環重合で進行 するが, 重合触媒が不要であり, 副生成物を発生せず, 寸 法安定性が良いという特徴がある。さらに，ポリベンゾオ キサジン樹脂は従来のフェノール樹脂の特徴である而熱 性・難燃性を保持している上に線熱膨張係数，吸水率，誘 電率などが低い。これらの特徴から, 電子材料, 接着剂,

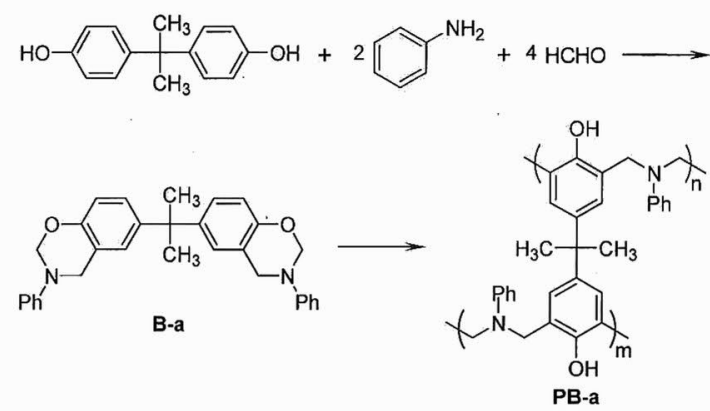

図 1 典型的なベンゾオキサジンモノマー, B-a とその硬化 物 PB-a

FRP のマトリックス樹脂, 精密機械部品などとしての利 用が期待されている。

ただし，ポリベンゾオキサジンには，その開環重合に約 $200^{\circ} \mathrm{C}$ 高温が必要であることや硬化生成物がややもろい などの欠点がある。また，代表的なポリベンゾオキサジン のガラス転移温度 $\left(T_{\mathrm{g}}\right)$ は約 $160^{\circ} \mathrm{C}$ であり， $T_{\mathrm{g}}$ 付近での眝 蔵弾性率の低下むかなり大きいことから，いっそう高い耐 熱性も期待されている。一方，ほとんどのモノマーは粉末 であり，ポリマーがあろいために薄いフィルムを作製する
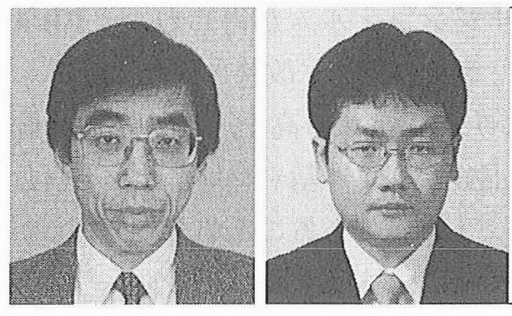

(左)

豊橋技術科学大学物質工学系 (441-8580 豊橋市天伯町雲雀ヶ丘 1-1) • 教授, 工学博士. 1979年 東京大学大学院工学研究科博士課程合成化学専攻単位取得退学. 専門は高性能高分子 材料.

** (右)

同上・助教, 博士 (理学). 2003年 大阪大学大学院基礎工学研究科化学系専攻博士後期課程修 了。専門は高分子合成. 
a) プロパルギル基を有するベンゾオキサジンモノマー
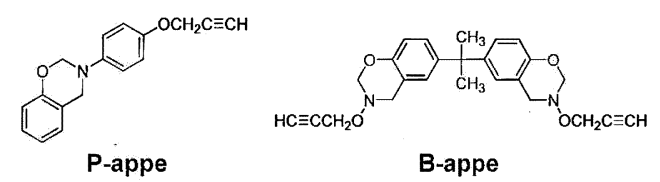

b) アリル基を有するベンゾオキサジンモノマー
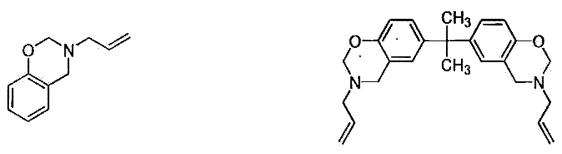

c) マレイミド基を有するベンゾオキサジンモノマー
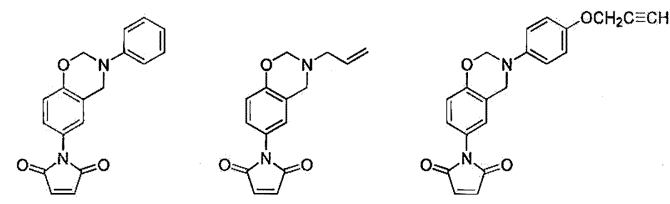

図 2 架橋性官能基を導入したベンゾオキサジンモノマー

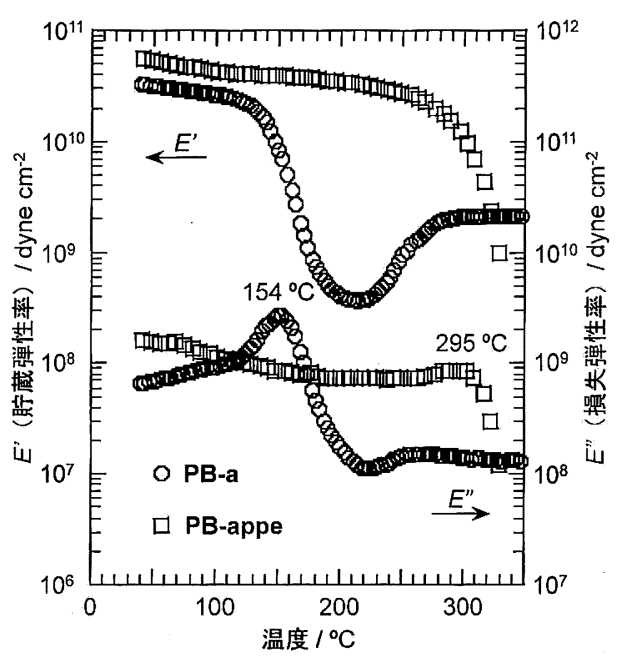

図 3 PB-a 抢よび PB-appe の粘弾性測定結果

ことが困難である。本稿では，これらの問題を解決するた めに試みられている種々の手法について紹介する。

\section{2. 新規な環状モノマーの合成と硬化特性}

ポリベンゾオキサジンの熱分解はアニリン成分の脱離が その要因となっていると報告されている21。そこで，アニ リン成分に架橋性官能基を結合させてネットワークを形成 することで分解生成物の揮発を抑え，結果として熱安定性 や力学特性を向上させることが行われている21。二重結合 や三重結合を有する架橋性官能基を導入することが有効で ある。Ishida らはエチニル基3)やニトリル基4を導入するこ とにより，耐熱性を大幅に向上できると報告している。

筆者らは架橋性官能基としてプロパルギル基を用い，2 官能性 (B-appe) と 1 官能性 (P-appe) のベンゾオキサジン を合成した5)（図 2a）。B-appe 拉よびP-appe では，開環 重合とプロパルギル基の架橋反応が並行してほぼ同じ温度 で起こる。 $240^{\circ} \mathrm{C} て ゙$ 熱処理して得られた新規なポリベンゾ

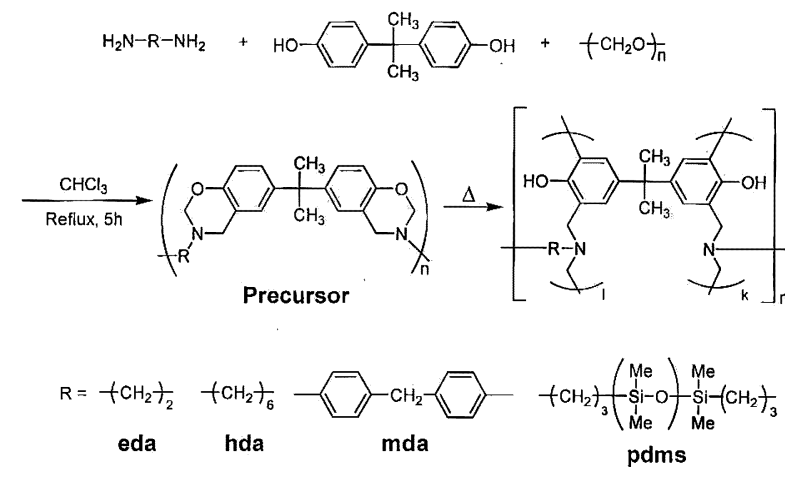

図 4 高分子量ベンゾオキサジン前駆体の合成

オキサジンの耐熱性は著しく向上する。たとえば，図 3 に

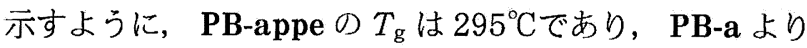
あ $100^{\circ} \mathrm{C}$ 以上高くなり, それに伴い, 眝蔵弾性率は $300^{\circ} \mathrm{C}$ 付近まで保持される。5\%重量減少温度 $\left(T_{5}\right)$ は $302^{\circ} \mathrm{C}$ (PB-a) から $352^{\circ} \mathrm{C}$ (PB-appe) にまで向上し, $800^{\circ} \mathrm{C}$ 以上で の残炭率む $32 \%$ 名ら $61 \%$ と高くなり，難燃性の向上にも 有効である。

ほかにも架橋性官能基としてアリル基(6)やエポキシ基7), マレイミド基8を導入したモノマーが合成されている （図 2)。また， $T_{\mathrm{g}}$ の向上を目指してアダマンタン骨格9や 籠状構造のポリヘドラルオリゴメリックシルセスキオキサ ン $(\mathrm{POSS})^{10)}$ を導入したモノマーや，勒性向上を目的とし て長鎖アルキル基 ${ }^{11)}$ を導入したモノマーなどあ報告されて いる。今後む，よりいっそう高性能で成形性に優れた新規 なモノマーの開発が期待される。

\section{3. 高分子量ベンゾオキサジン前駆体の 合成とその特徵}

従来, 低分子量の環状モノマーのみがポリベンゾオキサ ジンの原料モノマーとして検討され, 主鎖中に環状のベン ゾオキサジン構造を繰返し単位として有する高分子量前駆 体は報告がなかった。可溶性の高分子量ベンゾオキサジン 前駆体が合成できれば，薄膜の作製が容易になり，力学物 性の向上も期待でき, 従来の低分子量環状モノマーでは応 用できない分野にあ展開できる可能性がある。

ビスブェノル A, 各種ジアミン, ホルムアルデヒドを 適切に反応させることで高分子量のベンゾオキサジン前駆 体が，可溶性の白色粉末として得られた ${ }^{12)}$ (図 4)。重量平 均分子量は 6,000 8,900 と，それほど高くないが，前駆 体溶液汃ら容易に得られる自立性の薄膜を熱処理すること で, ポリベンゾオキサジンフィルムが得られた。PB-a フィルムと比較すると, 勒性が顕著に改善された（図 5)。 $T_{\mathrm{g}}$ は 238 $260^{\circ} \mathrm{C}$ なり, PB-a より高く, $T_{\mathrm{g}}$ 以上での貯 蔵弾性率も高くなる。長鎖アルキル基やシロキサンを含む ポリベンゾオキサジンであ同様であることから，それらが 可塑剂として機能していることをうかがわせる。 

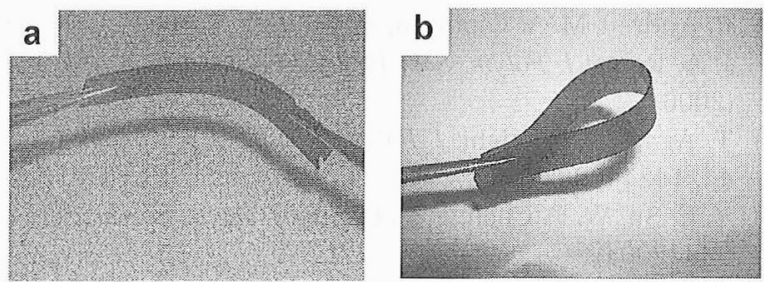

図 5 ポリベンゾオキサジンフィルムの外観 (a) PB-a, (b) PB-mda

アミノフェノール類とホルムアルデヒドを反応させるこ とで得られる $\mathrm{AB}$-タイプの非対称の高分子量前駆体加ら あ自己支持性の前駆体フィルムが得られ，熱処理によって 高い $T_{\mathrm{g}}\left(260 \sim 300^{\circ} \mathrm{C}\right)$ を有するフィルムとなる13)。最近, Yagci らはポリエーテルエステルの主鎖中にベンゾオキサ ジン骨格を導入した高分子量前駆体について報告してい $3^{14)}$ 。

\section{4. 高性能高分子とのポリマーアロイ}

高性能高分子とアロイ化することにより, ポリベンゾオ キサジンの特性を幅広い範囲で大きく向上させることがで きる。エポキシ樹脂やフェノール樹脂とのアロイ系はむっ とあ多く研究されている15), 16)。ポリベンゾオキサジンはそ のフェノール性水酸基を介してエポキシ樹脂と反応できる し, 従来型のフェノール樹脂はベンゾオキサジンの開環重 合の触媒であある。低粘度エポキシ樹脂とのブレンド系は 成形性の点加らも有利である。

Jang らは ATBN や CTBN などの液状ゴムを添加する と，ポリベンゾオキサジンの勒性が大幅に向上すると報告 している17)。液状ゴム添加エポキシ樹脂は $T_{\mathrm{g}}$ が低下する が，興味深いことに，液状ゴム添加ポリベンゾオキサジン 樹脂は $T_{\mathrm{g}}$ が高くなる ${ }^{18)}$ 。 ATBN 変性のポリベンゾオキサ ジンをヒドロキシフェニルマレイミド (HPMI) でさらに高 性能化することもできる ${ }^{19)}$ 。ポリウレタンとのアロイ化は ポリウレタンとフェノール樹脂との新規な複合化手法であ あるが，ポリウレタンの耐熱性の向上に有効であると同時 に，ポリベンゾオキサジンの勒性を大きく向上できる20\%。

ベンゾオキサジンモノマーとビスマレイミド (BMI) と を混合し熱処理することで, 而熱性や力学的特性が向上し たアロイ化フィルムが得られる211。ポリベンゾオキサジン のフェノール性水酸基と BMI の二重結合が反応し, 柔軟 なエーテル結合を介して $\mathrm{AB}$-共架橋構造を形成すると考 えられ，架橋密度が高くなるにあかかわらずフィルムはす ろくならず，アロイ化フィルムの $T_{\mathrm{g}}$ は一つだけである。 興味深いことに，アロイ系の $T_{\mathrm{g}}$ や残炭率はそれぞれの単 独樹脂よりも高い值を示した（図 6)。

代表的な耐熱性高分子であるポリイミドとのアロイ化に より, ポリベンゾオキサジンの勒性だけでなく, 而熱性も

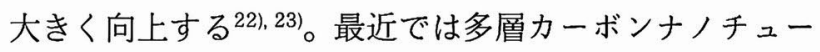

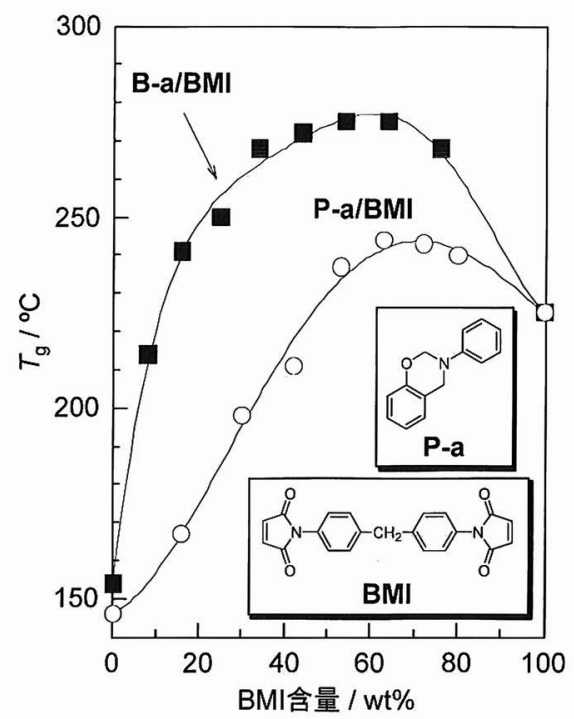

図 6 P-a/BMI および B-a/BMI 系ポリマーアロイにおい て, BMI 含量が $T_{\mathrm{g}}$ に及ぼす影響

ブ24)やイオン液体 ${ }^{25)}$ とのハイブリッド化についてあ報告さ れている。

\section{5. 有機-無機ハイブリッド}

\section{1 層状クレイとのナノコンポジット}

ポリマーとクレイとからなるナノコンポジットは新規な ナノ複合材料として注目されている。有機化モンモリロナ イト (MMT) を 2 5\%添加することで, ポリベンゾオキサ ジンの力学的㧍よび熱的性質が大きく向上する ${ }^{26) 。 ま た, ~}$ 有機化 MMT の触媒作用で, ベンゾオキサジンの開環重合 温度が低下する効果も観察された。クレイとして合成マイ カを用いてあポリベンゾオキサジンの性能を向上させるこ とができる27)。同様に，エポキシ/ポリベンゾオキサジン

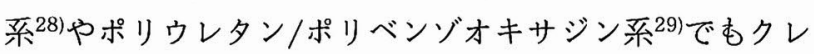
イの添加は有効である。

\section{2 ゾル-ゲル法による金属酸化物とのハイブリッド}

テトラエトキシシラン (TEOS) とベンゾオキサジンモ， マーとを混合し，水㧍よび酸触媒存在下で反応させ，最終 的に $240^{\circ} \mathrm{C}$ 熱処理することによりポリベンゾオキサジ ン/シリカ系八イブッリドを作製した ${ }^{30}$ 。ポリベンゾオキ サジン/チタニア系ハイブッリドあテトライソプロポキシ チタンを用いて同様に作製できる ${ }^{31}$ 。添加する酸触媒や生 成する $\mathrm{Si}-\mathrm{OH}$ などの酸性官能基の効果でオキサジンの開 環反応温度が低温側に大きくシフトする。透過型電子顕微 鏡観察や X 線回折により, 金属酸化物粒子がベンゾオキ サジンマトリックス中にナノレベルで分散していることを 確認した。シリカやチタニアを添加することで $T_{\mathrm{g}}$ は高温 側にシフトし， $T_{\mathrm{g}}$ 以上の高温での貯蔵弾性率む高い値を 保持した。 $T_{5}$ および残炭率む大きく向上し, マトリックス 中に均一に分散した金属酸化物がポリベンゾオキサジンの 
熱保護をしていると思われる。

高い柔軟性を有するポリジメチルシロキサン (PDMS) あ前駆体であるジェトキシジメチルシラン (DEDMS) のゾ ルーゲル反応によりハイブリッド化することが可能であ る ${ }^{32)}$ 。得られるハイブリッドフィルムは, PDMS の強勒化 効果により優れた柔軟性を示し，ポリベンゾオキサジン単 独フィルムよりも高い破断強度, 破断伸びを示す。また， PDMS の導入により耐熱性および難燃性も向上する。

\section{6. おわりに}

ポリベンゾオキサジンは環状モノマーの開環重合で得ら れる一連の新規なフェノール樹脂であり, 従来のフェノー ル樹脂とは異なる特性を多く有する。とくに，高い寸法安 定性は精密機械部品の作製に適している。難燃性であるこ とはハロゲンフリーに対応できるし，硬化過程で揮発性副 生成物を出さないので環境にも易しい。本稿では，新規な フェノール樹脂としてのポリベンゾオキサジンに関する最 近の進歩を述べたが，ポリベンゾオキサジンの高性能化・ 高機能化に向けて多くの試みが続いており，今後さらに大 きく発展すると思われる。基礎研究と応用研究が互いに刺 激し合い, 大きなブレークスルーに至る可能性を期待した $w_{0}$

\section{文献}

1）竹市 力, 小宮 璇, 高山雄二：強化プラスチック, 43,109 (1997)

2) H. Y. Low, H. Ishida: Polymer, 40, 4365 (1999)

3) H. J. Kim, Z. Brunovska, H. Ishida: Polymer, 40, 1815 (1999)

4) Z. Brunovska, H. Ishida: J. Appl. Polym. Sci., 73, 2937 (1999)

5) T. Agag, T. Takeichi: Macromolecules, 34, 7257 (2001)

6) T. Agag, T. Takeichi: Macromolecules, 36, 6010 (2003)
7) R. Andreu, M. A. Espinosa, M. Galia, V. Cadiz, J. C. Ronda, J. A. Reina: J. Polym. Sci., Part A: Polym. Chem., 44, 1529 (2006)

8) T. Agag, T. Takeichi: J. Polym. Sci., Part A: Polym. Chem., 44, 1424 (2006)

9) Y. C. Su, W. C. Chen, F. C. Chang: J. Appl. Polym. Sci., 94, $932(2004)$

10) Y. J. Lee, S. W. Kuo, Y. C. Su, J. K. Chen, C. W. Tu, F. C. Chang: Polymer, 45, 6321 (2004)

11) D. J. Allen, H. Ishida: J. Appl. Polym. Sci., 101, 2798 (2006)

12) T. Takeichi, T. Kano, T. Agag: Polymer, 46, 12172 (2005)

13) T. Agag, T. Takeichi: J. Polym. Sci., Part A: Polym. Chem., 45, 1878 (2007)

14) B. Kiskan, Y. Yagci, H. Ishida: J. Polym. Sci., Part A: Polym. Chem., 46, 414 (2008)

15) H. Ishida, D. J. Allen: Polymer, 37, 4487 (1996)

16) S. Rimdusit, H. Ishida: Polymer, 41, 7941 (2000)

17) J. Jang, D. Seo: J. Appl. Polym. Sci., 67, 1 (1998)

18) S. Katsuta, T. Kawauchi, T. Takeichi: Polym. Prepr., Jpn., 56,4285 (2007)

19) T. Agag, T. Takeichi: High Perform. Polym., 13, S327 (2001)

20) T. Takeichi, Y. Guo, T. Agag: J. Polym. Sci., Part A: Polym. Chem., 38, 4165 (2000)

21) T. Takeichi, Y. Saito, T. Agag, H. Muto, T. Kawauchi: Polymer, 49, 1173 (2008)

22) T. Takeichi, T. Agaga, R. Zeidam: J. Polym. Sci., Part A: Polym. Chem., 39, 2633 (2001)

23) T. Takeichi, Y. Guo, S. Rimdusit: Polymer, 46, 4909 (2005)

24) Q. Chen, R. Xu, D. Yu: Polymer, 47, 7711 (2006)

25) M. Ohara, T. Kawauchi, T. Takeichi: Polym. Prepr., Jpn., 56, 4289 (2007)

26) T. Takeichi, R. Zeidam, T. Agag: Polymer, 43, 45 (2002)

27) T. Agag, V. Taepaisitphongse, T. Takeichi: Polym. Compos., 28, 680 (2007)

28) T. Agag, T. Takeichi: High Perform. Polym., 14, 115 (2002)

29) T. Takeichi, Y. Guo: J. Appl. Polym. Sci., 90, 4075 (2003)

30) T. Agag, T. Takeichi: Mater. Sci. Forum, 449-452, 1157 (2004).

31) T. Agag, H. Tsuchiya, T. Takeichi: Polymer, 45, 7903 (2004)

32) H. Ardhyananta, M. H. Wahid, T. Kawauchi, T. Takeichi: Polym. Prepr., Jpn., 56, 4932 (2007) 